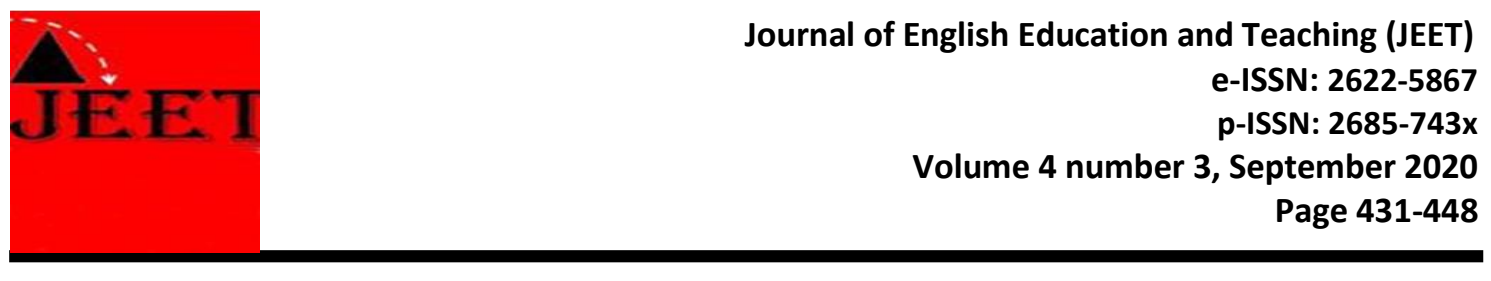

\title{
The Islamic Characters in Teaching English
}

\author{
Sefti Dedek Kendiani \\ SMA N 3 Lubuklinggau, South Sumatera \\ seftidedekkendiani@gmail.com \\ Corresponding email: seftidedekkendiani@gmail.com
}

\begin{abstract}
This study aims to determine the Islamic character implemented by the English Tadris lecturer in the learning process in the English Tadris Study Program at IAIN Curup. The method used was descriptive quantitative by using inferential percentage formula. The sample of this research is 127 students taken from the total number of English Tadris students, 234 students using the Hery King homogeny. The results of this study indicate the first $60.6 \%$ of lecturers implement religious aspects of greeting is Islam such as "Assalamualaikum, bismillahirrohmanirrohim, alhamdulillahirrobilalamin, in starting and ending lessons. Second, $48.8 \%$ of the lecturers implements aspects the lecturer uses clothes according to the Institut Agama Islam Negeri (IAIN) Curup code of ethics. Third, 47.2\% in aspect Appreciating Achievement, the statement used is that the lecturer gives high motivation to students to continue learning. Fourth, $44.2 \%$ in democratic aspect, and statement of this aspect namely lecturers are open in accepting student opinions. Fifth, $43.3 \%$ is the spirit of nationality aspect, the statements in this aspect are the lecturers commemorate national (Indonesian Independence day, Heroes day, mother's day, etc) and Islamic day (Maulid of the Prophet Muhammad SAW, Halal bi halal, Islamic Miraj, Islamic new year).
\end{abstract}

Keywords : Teaching English, Islamic Characters.

\section{Introduction}

In this millennium era, education is one of the most important and valuable provisions for a better future. education is also one of the main keys to progressing whether or not a country. as we know that Education will definitely produce good quality Human Resources in terms of one's spiritual, intelligence and skills which is the process of printing the next generation of nations. In achieving educational success, there are several element that affects it. One of them is a teacher. Teachers have an important role in the education system itself. Because, they are directly involved in educational activities. Teaching like that and explain the lesson. On the other hand, people nowadays more aware of the importance of education, but more and more what's important is how education is carried out (Apriani 2017). To realize quality human resources in 
spiritual, intelligence and skill certainly character education plays a serious role in it. Character education or character education since the beginning of its emergence in education has been regarded as something that is inevitable by experts. John Dewey, for example, as quoted by Frank G. Goble in 1916, once said, "it is common in educational theory that the formation of character is the general goal of teaching and education of character in schools (Ainissyifa 2014). Character education in Indonesia has indeed run as in several other countries, such as in England, America and Finland. However, if you look at the results compared to the countries that have been mentioned, Indonesia is still far behind. This is because education in Indonesia currently emphasizes mastery of scientific aspects, intelligence and less attention or neglect of character education. Knowledge of the moral rules obtained in moral or ethical education in schools is now increasingly abandoned because of the government's lack of attention to character education. So don't be surprised if many millennials of Indonesia are trapped in free life, many consume drugs and have sex without ties. The character in education is the spirit in Islamic education. Islamic education and character in education for students with better character and values. It is clear that Islamic education with detailed guidance will never be separated from al-Qur 'an and al-Sunnah in accordance with the character in education, for example building students with good morals (Apriani, Fathurrochman, and Harmi 2018).

The basic principles of character development in Indonesia have actually been formulated in the functions and objectives of national education. Article 3 of Law Number 20 Year 2003 concerning the National Education System, states that "National education functions to develop capabilities and shape the character and civilization of a dignified nation in the context of educating the life of the nation, aiming at developing the potential of students to become human beings who believe and be devoted to God Almighty, noble, healthy, knowledgeable, capable, creative, independent, and become citizens who are democratic and responsible "(Fitri 2018). Character education in Islamic education institutions, may be better than the application of character education in other educational institutions, it's just whether it is in accordance with the views of the community, because 
they are a group of people who feel about how character education is applied in Islamic educational institutions(Adu 2014).

Regarding character education, it can be seen from the function of Islamic education, which is to make humans able to develop all their potential so that they function optimally in accordance with the rules outlined by Allah. And Rasulullah SAW. which will eventually be realized as a whole human being (insan kamil). Here, the function of Islamic education is a manifestation of the ideals of life to preserve, instill, and transform Islamic values to the next generation so that the religious cultural values aspired to continue to function and develop in accordance with the progress of the times and technology (Fitri 2018).

Therefore the development of Islamic character is very necessary to create a generation who is polite in speaking words and having a good character. As the Prophet said

Rasulullah SAW:

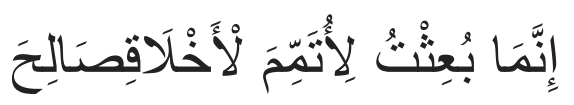

It means: "Indeed, I was sent only to perfect noble character."

From these words it has been said to perfect noble morals for mankind. Therefore, an important role as educators / lecturers is the success or failure of learning depends on the accountability and ability of educators in carrying out their duties(Sabila 2015). Educators are recognized as a major factor in the process of education without educators, the education process will not be realized, other than that increasingly. The better the quality of the educator, the better the education process, especially the interaction process of educators and students, which are the main activities in the education process. Reality lately shows how many problems include educators so that the educational process has not run as expected. Of all the problems that exist in educators is that most of the people who carry the teaching / teacher profession are merely professions that have not been engraved in their souls as educators, also most of the educators have not acted as real educators but only as transferred of knowledge. the Islamic soul is a mua'llim who acts as a person who transfers knowledge to students at the same time he is also a mu'addib who prepares students to be responsible for developing a quality of 
life in the future, he is also a religious teacher, murshid, mudarris and mudarrih (Aziz 2015).

As long as these values do not conflict with Islamic values, that's certainly not why. However, cultural differences and thoughts that are not in accordance with what Islam has taught must be explained by English teachers so that their students do not just imitate these values. The whole learning process should be a means for the realization of an integrated investment in Islamic values. If teachers provide assistance during cultural transfer, students are expected to be more careful when they are dealing with TV or the internet so that they can filter and not just copy what is witnessed from the media (Amelia 2012).

Institut Agama Islam Negeri (IAIN) Curup is one of the Islamic-based tertiary institutions. Certainly different from public universities. In the IAIN Curup profile website, that this Islamic tertiary institution will foster and educate members of the community so as to produce Islamic, Intellectual and Professional Moral Scholars in their fields and be useful for the development of the nation and state in the future. Everything is directed at the development and empowerment of the Tri Dharma of Higher Education, namely the dharma of education and teaching, the dharma of research, and the dharma of community service. one of Curup other study programs that received " $A$ " accreditation was the English Study Program. In teaching and learning English, there are four language skills that students must master; they read, listen, speak and write(Gusmuliana and Fitri 2016, Diani, et . al 2019; Syafryadin, 2020; Syafryadin, et al; 2020), but in this study all learning is taken from English. With this accreditation, it demands that lecturers of English study programs not only be intelligent intellectual but also demand good character, especially Islamic characters. The characters that must be possessed by lecturers according to the Ministry of Education and Culture and in line with Islamic teachings are 18 characters namely religious, honest, tolerance, discipline, hard work, creative, independent, democratic, curiosity, national spirit, love of the motherland, respect for achievement, friendship or communicative, love peace, love to read, care about the environment, care about social, responsibility.

Yuliyawati (2010) stated that there were seven positive female lecturers known, namely patient, kind, conscientious, tolerant, friendly, caring, and neat 
and four negative characters, namely angry, vindictive, talkative, and easily offended (Yuliyawati, 2010). Eliyyil (2015) research As for the values applied in faith, piety, discipline, critical, analytical, intelligent, clean, healthy, cheerful, competitive, respectful, friendly, caring, tolerant, work loud, respectful. From this research it is known that the importance of lecturers implementing Islamic character in the learning process. Therefore, this research focused on the Islamic character of lecturers applied in learning English in the English Study Program Curriculum IAIN.

\section{Research Methodology}

This research used descriptive quantitative method. Hancock, Ockleford \& Windridge (2009) claimed that qualitative research aims to help us to understand the social word in which we live and why things are the way they are. This study finds out about the implementation of Islamic character by English study program lecturers in the learning process. This research is a study based on character values issued by the Ministry of Education and Culture.

The purpose of this research is to find out what aspects are implemented in the process of learning English from 18 aspects that have been determined by the Ministry of Education and Culture. Because English teacher lecturers must still have Islamic character values in teaching because they are in the scope of Islamic tertiary institutions, including teaching English.

During the covid-19 pandemic as it is today, descriptive studies are designed to find out the results that are consistent with what the lecturer is doing when teaching. in this study there were populations of 234 English study program students.

Tabel 1. Population

\begin{tabular}{|c|l|l|}
\hline Number & Class & Total \\
\hline 1 & TBI IIA & 25 \\
\hline 2 & TBI IIB & 24 \\
\hline 3 & TBI IIC & 22 \\
\hline 4 & TBI IVA & 21 \\
\hline 5 & TBI IVB & 16 \\
\hline 6 & TBI IVC & 18 \\
\hline
\end{tabular}




\begin{tabular}{|c|c|c|}
\hline 7 & TBI VIA & 16 \\
\hline 8 & TBI VIB & 17 \\
\hline 9 & $\mathrm{TBI} \mathrm{VIC}$ & 25 \\
\hline 10 & TBI VIIIA & 28 \\
\hline 11 & TBI VIIIB & 22 \\
\hline \multicolumn{2}{|c|}{ Total } & 234 \\
\hline
\end{tabular}

so researchers used the Hery King nomogram table so that a sample of 127 students was obtained with a significance level of $10 \%$.

The research data collection instrument was based on the theory of the Ministry of Education and Culture and was validated by 4 experts in their fields, namely: 1) PGRI Palembang University, 2) Raden Fattah State Islamic University Palembang, 3) Bengkulu University, 4) Curup State Islamic Religion Institute. This instrument consists of 8 indicators, each of which has 2 statements and a total of 36 instruments used. With the score items as follows:

$\begin{array}{ll}\text { Always } & : 5 \\ \text { Often } & : 4 \\ \text { Sometimes } & : 3 \\ \text { Seldom } & : 2 \\ \text { Never } & : 1\end{array}$

Research data analysis was conducted on each question from each aspect. for all statistical data, descriptive, as well as the average score was taken from the responses of participants who were right numbered 127 respondents.

\section{Findings and Discussion,}

\section{Findings}

The summarizes the results of an analysis of questionnaires that have been distributed and filled out by 127 respondents. Implementation of 18 aspects of education implemented by lecturers in teaching English there are only a few aspects which have the highest percentage of its aspects compared to other aspects. Standard deviation scores have been summarized in the table. The following are the results of this research: 
Kendiani, Apriani, Gusmuliana

The Islamic Characters in Teaching English

Table 1 : Presentation of the questionnare

\begin{tabular}{|c|c|c|c|c|c|c|}
\hline Indikator & Statement & Always & Often & $\begin{array}{l}\text { Someti } \\
\text { mes }\end{array}$ & Seldom & never \\
\hline \multirow[t]{5}{*}{ 1. Religius } & 1. In the learning & 77 & 24 & 23 & 2 & 1 \\
\hline & process lecturers & $(60,6 \%)$ & $(18,9 \%)$ & $(18,1 \%)$ & $(1,6 \%)$ & $10,8 \%$ \\
\hline & $\begin{array}{l}\text { say greetings } \\
\text { (assalamualaiku } \\
\text { m, Bismillah, } \\
\text { Alhamdulillah) }\end{array}$ & & & & & 1 \\
\hline & 2. The lecturer & 49 & 37 & 31 & 10 & - \\
\hline & $\begin{array}{l}\text { reminds students to } \\
\text { obey worship } \\
\text { (pillars of Islam) }\end{array}$ & $(38,6 \%)$ & $(29,1 \%)$ & $(24,4 \%)$ & $(7,9 \%)$ & \\
\hline \multirow[t]{4}{*}{ 2. Be honest } & 3. The lecturer & 52 & 38 & 32 & 5 & - \\
\hline & $\begin{array}{l}\text { grades students } \\
\text { according to the } \\
\text { evaluation } \\
\text { results. }\end{array}$ & $(40,9 \%)$ & $(29,9 \%)$ & $(25,2 \%)$ & $(3,9 \%)$ & - \\
\hline & 4. The lecturer give & 36 & 38 & 40 & 10 & 3 \\
\hline & $\begin{array}{l}\text { strict sanctions to } \\
\text { students who } \\
\text { commit fraud } \\
\text { during exam. }\end{array}$ & $(28,3 \%)$ & $(29,9 \%)$ & $(31,5 \%)$ & $(7,9 \%)$ & $\begin{array}{c}(2,4 \% \\
)\end{array}$ \\
\hline \multirow[t]{4}{*}{ 3. Tolerance } & 5. The lecturer lets & 47 & 32 & 34 & 11 & 3 \\
\hline & $\begin{array}{l}\text { students come to } \\
\text { class when they } \\
\text { come late with the } \\
\text { opportunity given } \\
3 \text { times. }\end{array}$ & (37\%) & $(25,2 \%)$ & $(26,8 \%)$ & $(8,7 \%)$ & $\begin{array}{c}(2,4 \% \\
)\end{array}$ \\
\hline & 6. The lecturers & 46 & 33 & 41 & 6 & - \\
\hline & $\begin{array}{l}\text { allow students who } \\
\text { are unable attend } \\
\text { due to illness }\end{array}$ & $(36,5 \%)$ & $(26,2 \%)$ & $(32,5 \%)$ & $(4,8 \%)$ & - \\
\hline \multirow[t]{2}{*}{ 4. Discipline } & $\begin{array}{l}\text { 7. Lecturers } \\
\text { dress }\end{array}$ & $\begin{array}{c}62 \\
(48,8 \%)\end{array}$ & $\begin{array}{c}36 \\
(28,3 \%)\end{array}$ & $\begin{array}{c}18 \\
(14,2 \%)\end{array}$ & $\begin{array}{c}10 \\
(7,9 \%)\end{array}$ & $\begin{array}{c}1 \\
10,8 \%\end{array}$ \\
\hline & $\begin{array}{l}\text { according to } \\
\text { the IAIN } \\
\text { Curup Code } \\
\text { of Ethics. }\end{array}$ & & & & & 1 \\
\hline
\end{tabular}




\begin{tabular}{|c|c|c|c|c|c|c|}
\hline & $\begin{array}{l}\text { 8. The lecturer } \\
\text { distinguishes } \\
\text { between male } \\
\text { and female seats } \\
\text { in the learning } \\
\text { process. }\end{array}$ & $\begin{array}{c}39 \\
(30,2 \%)\end{array}$ & $\begin{array}{c}28 \\
(21,7 \%)\end{array}$ & $\begin{array}{c}38 \\
(29,5 \%)\end{array}$ & $\begin{array}{c}16 \\
(12,4 \%)\end{array}$ & $\begin{array}{c}8 \\
(6,2 \% \\
1\end{array}$ \\
\hline \multirow[t]{2}{*}{ 5. Hard work } & $\begin{array}{l}\text { 9. The lecturer } \\
\text { completes } 16 \\
\text { meetings in } 1 \\
\text { semester }\end{array}$ & $\begin{array}{c}38 \\
(29,7 \%)\end{array}$ & $\begin{array}{c}32 \\
(25 \%)\end{array}$ & $\begin{array}{c}39 \\
(30,5 \%)\end{array}$ & $\begin{array}{c}17 \\
(13,3 \%)\end{array}$ & $\begin{array}{c}2 \\
(1,6 \% \\
1\end{array}$ \\
\hline & $\begin{array}{l}\text { 10. The lecturer } \\
\text { encourage } \\
\text { students to make } \\
\text { achievements }\end{array}$ & $\begin{array}{c}37 \\
(28,7 \%)\end{array}$ & $\begin{array}{c}45 \\
34,9 \%\end{array}$ & $\begin{array}{c}35 \\
(27,1 \%)\end{array}$ & $\begin{array}{c}9 \\
(7 \%)\end{array}$ & $\begin{array}{c}3 \\
(2,3 \% \\
1\end{array}$ \\
\hline \multirow[t]{2}{*}{ 6. Creative } & $\begin{array}{l}\text { 11. Lecturers use } \\
\text { various kinds of } \\
\text { learning media. }\end{array}$ & $\begin{array}{c}38 \\
(29,5 \%)\end{array}$ & $\begin{array}{c}47 \\
(36,4 \%)\end{array}$ & $\begin{array}{c}31 \\
(24 \%)\end{array}$ & $\begin{array}{c}12 \\
(9,3 \%)\end{array}$ & $\begin{array}{c}1 \\
(0,8 \% \\
1\end{array}$ \\
\hline & $\begin{array}{l}\text { 12. Lecturers use } \\
\text { various learning } \\
\text { models }\end{array}$ & $\begin{array}{c}32 \\
(24,8 \%)\end{array}$ & $\begin{array}{c}42 \\
(32,6 \%)\end{array}$ & $\begin{array}{c}43 \\
33,3 \%\end{array}$ & $\begin{array}{c}10 \\
(7,8 \%)\end{array}$ & $\begin{array}{c}2 \\
(1,6 \% \\
)\end{array}$ \\
\hline \multirow[t]{2}{*}{$\begin{array}{l}\text { 7.Independ } \\
\text { ent }\end{array}$} & $\begin{array}{l}\text { 13. The lecturer } \\
\text { continue to teach } \\
\text { even with } \\
\text { makeshift facilities }\end{array}$ & $\begin{array}{c}35 \\
(27,1 \%)\end{array}$ & $\begin{array}{c}43 \\
(33,3 \%)\end{array}$ & $\begin{array}{c}35 \\
(27,1)\end{array}$ & $\begin{array}{c}12 \\
(9,3 \%)\end{array}$ & $\begin{array}{c}4 \\
(3,1 \% \\
)\end{array}$ \\
\hline & $\begin{array}{l}\text { 14. The lecturer } \\
\text { correct the exam } \\
\text { results themselves. }\end{array}$ & $\begin{array}{c}45 \\
35,2 \%\end{array}$ & $\begin{array}{c}46 \\
(35,9 \%)\end{array}$ & $\begin{array}{c}31 \\
(24,2 \%)\end{array}$ & $\begin{array}{c}5 \\
3,9 \%\end{array}$ & $\begin{array}{c}1 \\
(0,8 \% \\
1\end{array}$ \\
\hline \multirow[t]{2}{*}{$\begin{array}{l}\text { 8. Democrat } \\
\text { ic }\end{array}$} & $\begin{array}{l}\text { 15. Lecturers are } \\
\text { open in accepting } \\
\text { student opinions }\end{array}$ & $\begin{array}{c}57 \\
(44,2 \%)\end{array}$ & $\begin{array}{c}40 \\
(31 \%)\end{array}$ & $\begin{array}{c}23 \\
(17,8 \%)\end{array}$ & $\begin{array}{c}8 \\
(6,2 \%)\end{array}$ & $\begin{array}{c}1 \\
(0,8 \% \\
1\end{array}$ \\
\hline & $\begin{array}{l}\text { 16. lecturer } \\
\text { behave the same } \\
\text { toward students } \\
\text { from all walks of } \\
\text { life }\end{array}$ & $\begin{array}{c}33 \\
(25,8 \%)\end{array}$ & $\begin{array}{c}36 \\
(28,1 \%)\end{array}$ & $\begin{array}{c}49 \\
(38,3 \%)\end{array}$ & $\begin{array}{c}8 \\
(6,3 \%)\end{array}$ & $\begin{array}{c}2 \\
(1,6 \% \\
1\end{array}$ \\
\hline \multirow[t]{2}{*}{ 9. Curiosity } & $\begin{array}{l}\text { 17. The lecturer } \\
\text { asks the presence } \\
\text { of students before } \\
\text { learning begins }\end{array}$ & $\begin{array}{c}47 \\
(36,4 \%)\end{array}$ & $\begin{array}{c}43 \\
(33,3 \%)\end{array}$ & $\begin{array}{c}27 \\
20,9 \%\end{array}$ & $\begin{array}{c}12 \\
(9,3 \%)\end{array}$ & $\begin{array}{l}- \\
-\end{array}$ \\
\hline & $\begin{array}{l}\text { 18. The Lecturer } \\
\text { understands the } \\
\text { character of each } \\
\text { students }\end{array}$ & $\begin{array}{c}28 \\
(22,2 \%)\end{array}$ & $\begin{array}{c}28 \\
(22,2 \%)\end{array}$ & $\begin{array}{c}52 \\
(41,3 \%)\end{array}$ & $\begin{array}{c}15 \\
(11,9 \%)\end{array}$ & $\begin{array}{c}3 \\
(2,4 \% \\
1\end{array}$ \\
\hline 10. The spirit & 19. The Lecturers & 55 & 34 & 28 & 7 & 3 \\
\hline
\end{tabular}




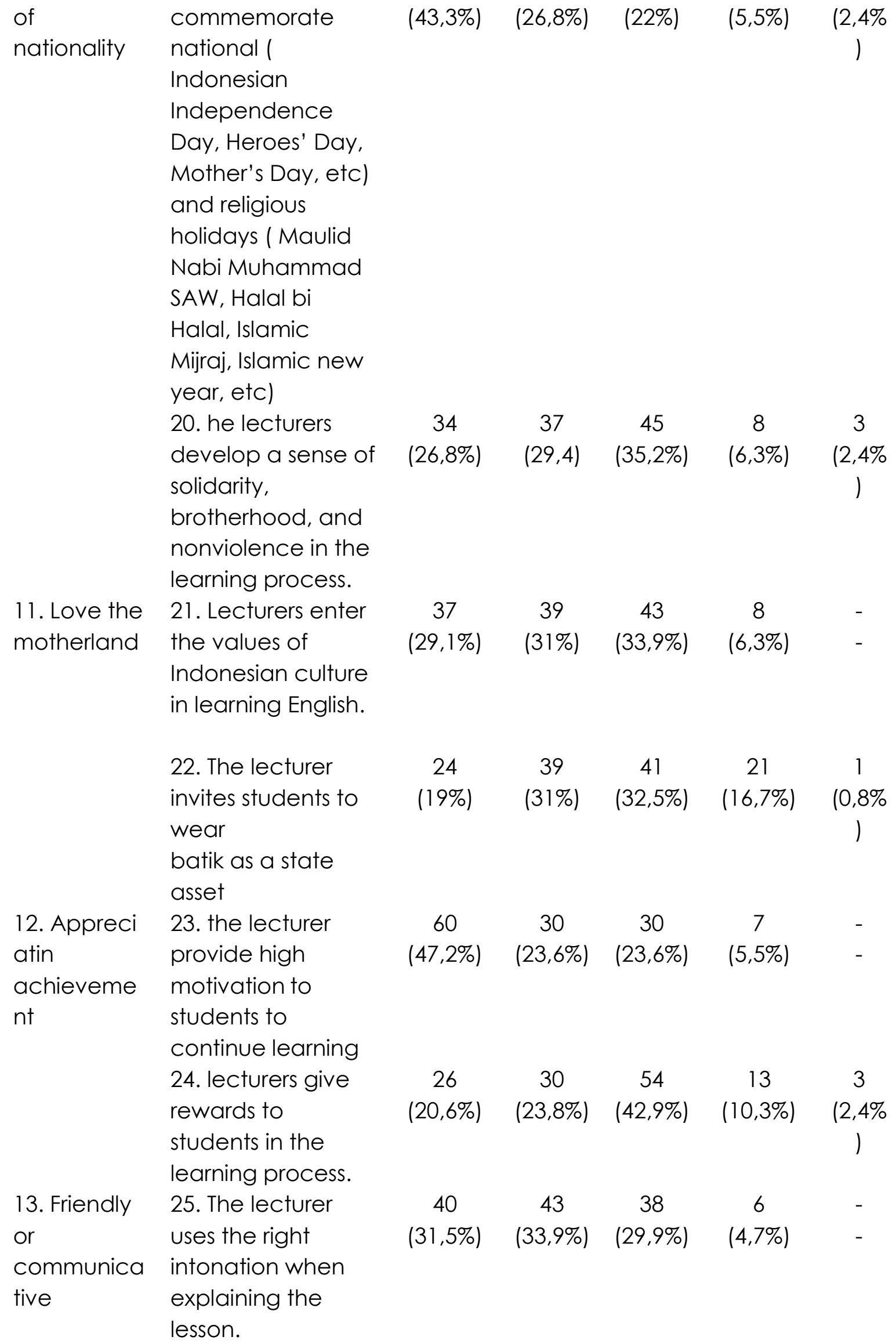




\begin{tabular}{|c|c|c|c|c|c|c|}
\hline & $\begin{array}{l}\text { 26. The lecturer } \\
\text { said politely that } \\
\text { contains Islamic } \\
\text { sentences } \\
\text { (masyaallah, } \\
\text { subhanallah, } \\
\text { allahuakbar, } \\
\text { astagfirullah) in } \\
\text { learning process }\end{array}$ & $\begin{array}{c}30 \\
(23,8 \%)\end{array}$ & $\begin{array}{c}41 \\
(32,5 \%)\end{array}$ & $\begin{array}{c}36 \\
(28,6 \%)\end{array}$ & $\begin{array}{c}18 \\
(14,3 \%)\end{array}$ & $\begin{array}{c}1 \\
10,8 \% \\
1\end{array}$ \\
\hline \multirow[t]{2}{*}{$\begin{array}{l}\text { 14. Peace in } \\
\text { love }\end{array}$} & $\begin{array}{l}27 . \text { In the } \\
\text { learning } \\
\text { process } \\
\text { lecturers are } \\
\text { polite and } \\
\text { polite in } \\
\text { learning }\end{array}$ & $\begin{array}{c}41 \\
(32,3 \%)\end{array}$ & $\begin{array}{c}43 \\
(33,9 \%)\end{array}$ & $\begin{array}{c}37 \\
(29,1 \%)\end{array}$ & $\begin{array}{c}5 \\
(3,9 \%)\end{array}$ & $\begin{array}{c}1 \\
10,8 \% \\
1\end{array}$ \\
\hline & $\begin{array}{l}\text { 28. Lecturers foster } \\
\text { a sense of family in } \\
\text { the learning } \\
\text { process. }\end{array}$ & $\begin{array}{c}31 \\
(24,4 \%)\end{array}$ & $\begin{array}{c}42 \\
(33,1 \%)\end{array}$ & $\begin{array}{c}43 \\
(33,9 \%)\end{array}$ & $\begin{array}{c}10 \\
(7,9 \%)\end{array}$ & $\begin{array}{c}1 \\
10,8 \% \\
1\end{array}$ \\
\hline \multirow[t]{2}{*}{$\begin{array}{l}\text { 15. Like to } \\
\text { read }\end{array}$} & $\begin{array}{l}29 . \text { The lecturer } \\
\text { asks students to } \\
\text { read many } \\
\text { references } \\
\text { before the } \\
\text { lecture schedule } \\
\text { begins. }\end{array}$ & $\begin{array}{c}51 \\
(40,2 \%)\end{array}$ & $\begin{array}{c}36 \\
(28,3 \%)\end{array}$ & $\begin{array}{c}34 \\
(26,8 \%)\end{array}$ & $\begin{array}{c}4 \\
(3,1 \%)\end{array}$ & $\begin{array}{c}2 \\
(1,6 \% \\
1\end{array}$ \\
\hline & $\begin{array}{l}\text { 30. The lecturer } \\
\text { asks students to } \\
\text { bring books } \\
\text { related to learning } \\
\text { material }\end{array}$ & $\begin{array}{c}42 \\
(33,3 \%)\end{array}$ & $\begin{array}{c}39 \\
(31 \%)\end{array}$ & $\begin{array}{c}34 \\
(26,8 \%)\end{array}$ & $\begin{array}{c}10 \\
(7,9 \%)\end{array}$ & $\begin{array}{c}2 \\
(1,6 \% \\
1\end{array}$ \\
\hline \multirow[t]{2}{*}{$\begin{array}{l}\text { 16.Care for } \\
\text { the } \\
\text { environmen } \\
t\end{array}$} & $\begin{array}{l}31 . \text { Lecturers } \\
\text { suggest to } \\
\text { always } \\
\text { maintain } \\
\text { cleanliness }\end{array}$ & $\begin{array}{c}46 \\
(36,2 \%)\end{array}$ & $\begin{array}{c}48 \\
(37,8 \%)\end{array}$ & $\begin{array}{c}28 \\
(22 \%)\end{array}$ & $\begin{array}{c}4 \\
(3,1 \%)\end{array}$ & $\begin{array}{c}1 \\
10,8 \% \\
1\end{array}$ \\
\hline & $\begin{array}{l}\text { 32. Lecturers } \\
\text { manage the class } \\
\text { well (tidying the } \\
\text { seating, prepare } \\
\text { the lecturers table, } \\
\text { etc.) }\end{array}$ & $\begin{array}{c}27 \\
(21,3 \%)\end{array}$ & $\begin{array}{c}43 \\
(33,9 \%)\end{array}$ & $\begin{array}{c}42 \\
(33,1 \%)\end{array}$ & $\begin{array}{c}14 \\
(11 \%)\end{array}$ & $\begin{array}{c}1 \\
10,8 \% \\
1\end{array}$ \\
\hline
\end{tabular}




\begin{tabular}{|c|c|c|c|c|c|c|}
\hline \multirow{3}{*}{$\begin{array}{l}\text { 17. Social } \\
\text { care }\end{array}$} & 33. Attitudes and & 50 & 39 & 28 & 10 & - \\
\hline & $\begin{array}{l}\text { actions that } \\
\text { always want to } \\
\text { provide } \\
\text { assistance to } \\
\text { others and } \\
\text { people in need. }\end{array}$ & $(39,4 \%)$ & $(30,7 \%)$ & $(22 \%)$ & $(7,9 \%)$ & - \\
\hline & $\begin{array}{l}\text { 34. The lecturers } \\
\text { provide assistance } \\
\text { to underprivileged } \\
\text { students }\end{array}$ & $\begin{array}{c}24 \\
(19 \%)\end{array}$ & $\begin{array}{c}35 \\
(27,8 \%)\end{array}$ & $\begin{array}{c}37 \\
(29,4 \%)\end{array}$ & $\begin{array}{c}26 \\
(20,6 \%)\end{array}$ & $\begin{array}{c}4 \\
(3,2 \% \\
1\end{array}$ \\
\hline \multirow[t]{2}{*}{$\begin{array}{l}\text { 18. Responsi } \\
\text { bility }\end{array}$} & $\begin{array}{l}\text { 35. The lecturer } \\
\text { ensures that } \\
\text { each student } \\
\text { understands } \\
\text { the lecture } \\
\text { material. }\end{array}$ & $\begin{array}{c}39 \\
(30,7 \%)\end{array}$ & $\begin{array}{c}37 \\
(29,1 \%)\end{array}$ & $\begin{array}{c}41 \\
(32,3 \%)\end{array}$ & $\begin{array}{c}8 \\
(6,3 \%)\end{array}$ & $\begin{array}{c}8 \\
16,3 \% \\
1\end{array}$ \\
\hline & $\begin{array}{l}\text { The lecturers give } \\
\text { grades according } \\
\text { to students and } \\
\text { can be justified }\end{array}$ & $\begin{array}{c}40 \\
(31,7 \%)\end{array}$ & $\begin{array}{c}37 \\
(29,4 \%)\end{array}$ & $\begin{array}{c}37 \\
(29,4 \%)\end{array}$ & $\begin{array}{c}11 \\
(8,7 \%)\end{array}$ & $\begin{array}{c}1 \\
10,8 \% \\
1\end{array}$ \\
\hline
\end{tabular}

From the percentage, it can see in the aspect 1 that there are 77 students who confirm that the lecturer implements Assalamualaikum, bismillah, and alhamdulillah when starting and ending the lesson with a percentage of $60,6 \%$. then, there are 49 students who justify that the lecturer implements to always remind to worship according to the pillars of Islam with a percentage of $38,6 \%$.

Aspect 2 , there are 52 students who approve the lecturer to assess the results of the assessment with a percentage of $40,9 \%$. then for the statement the lecturer gave sanctions to students who cheated during the exam as many as 36 students with a percentage of $28,3 \%$ stated that sometimes the lecturer implements it.

Aspect 3, there are 47 students with percentage of $37 \%$ stated that the lecturer gives students the opportunity to enter class if they are late with the opportunity limit 3 times. Then, there are 46 students with percentage of $36,5 \%$ stated that The lecturer allows students who cannot attend due to illness.

Aspect 4, it can see that there are 62 students with percentage of $48,8 \%$ stated that lecturers dress according to the IAIN Curup Code of Ethics. Then, there are 39 students with percentage of $30,2 \%$ stated that lecturer 
distinguishes between male and female seats in the learning process.

Aspect 5, there are 38 students with $29,7 \%$ stated lecturers rarely complete 16 meetings in 1 semester. Then, there are 37 students with percentage of $28,7 \%$ stated that the lecturer always encourage students to make achievements.

Aspect 6, it can see that there are 38 students with percentage of $29,5 \%$ stated that lecturer often use various kinds of learning media. Then, there are 32 students with percentage of $24,8 \%$ stated that the lecturer use various learning models.

Aspect 7, it can see that, there are 35 students with percentage of $27,1 \%$ stated that the lecturer continue to teach even with makeshift facilities. Then, there are 45 students with percentage of $35,2 \%$ stated that the lecturer correct the exam results themselves.

Aspect 8, it can see that, there are 57 students with percentage of $44,2 \%$ stated that the lecturers are always open in accepting students opinion. Then, there are 33 students with percentage 25,8\% stated that the lecturer behave the same toward students from all walks of life.

Aspect 9, it can see been that, there are 47 students with percentage of $36,4 \%$ stated that the lecturer always asks the presence of students before learning learning begins. Then, there are 28 students with percentage of $22,2 \%$ stated that the lecturer always understands the character of each students.

Aspect 10, it can see that, there are 55 students with percentage of $43,3 \%$ stated that the lecturer always commemorate national and Islamic day. Then, there are 34 students with percentage of $26,8 \%$ stated that the lecturer always develop a sense of solidarity, brotherhood, and nonviolence in the learning process.

Aspect 11, it can see that there are 37 students with percentage of $29,1 \%$ stated that the lecturer always enter the values of Indonesian culture in learning English. Then, there are 24 students with percentage of $19 \%$ stated that the lecturer always invites students to wear batik as a state asset.

Aspect 12, it can see that there are 60 students with percentage of $47,2 \%$ stated that the lecturer always provide high motivation to students to continue learning. Then, there are 26 students with percentage of $20,6 \%$ stated that lecturer always give reward to students in the learning process. 
Aspect 13, it can see that there are 40 students with percentage of $31,5 \%$ stated that the lecturer often use the right intonation in the explain the lesson. Then, there are 30 students with percentage of $23,8 \%$ stated that the lecturer always said politelt that contains Islamic sentences.

Aspect 14, it can see that there are 41 students with percentage of $32,3 \%$ stated that the lecturer implement the polite in learning. Then, there are 31 students with percentage of $24,4 \%$ stated that the lecturer implement foster a sense of family in the learning process.

Aspect 15, it can see that there are 51 students with percentage 40,2\% stated that the lecturer always asks students to read many references before the schedule begins. Then, there are 42 students with percentage 33,3\% stated that the lecturer always asks students to bring books related to learning material.

Aspect 16, it can see that there are 46 with percentage of $36,2 \%$ stated that the Lecturers always suggest to always maintain cleanliness. Then, there are 27 students with the percentage $21,3 \%$ stated that the lecturer manage the class well.

Aspect 17, it can see that there are 50 students with percentage of $39,4 \%$ stated that the attitudes and action that always want to provide assistance to other and people in need. Then, there are 24 students with percentage of $19 \%$ stated that the lecturer sometimes provide assistance to underprivileged students.

Aspect 18, it can see that there 39 students with percentage of $30,7 \%$ stated that the lecturer ensures that each student understands the lecturer material. Then, there are 40 students with percentage of $31,7 \%$ stated that the lecturer always give grades according to students and can be justified.

\section{Discussion}

The term character which in English is usually called this character according to Wynne in 1991 comes from Greek which means "to mark" and focuses on how to apply the value of goodness in the form of action or behavior. In other words, the term character is very closely related to one's personality where someone can be said to be a person of character if his 
behavior is in accordance with applicable moral rules. Meanwhile, according to Mark Rutland in 2009 the word character can be interpreted as "chiseled". He added that basically the character can be formed early so that the person has mental, moral, and moral qualities that are in accordance with the norm. From the two opinions above, we can conclude that the characters contain two things, namely values and personality. Meanwhile, in terminology the character words according to the Big Indonesian Dictionary in 2008 are interpreted as psychiatric, moral or moral characteristics that distinguish one person from another; character or character (Arif 2017).

Character education is a system of character values that includes components of knowledge, awareness or will, and actions to carry out these values, both to God Almighty, self, others, the environment, and nationality ( $N$ 2005). As for character education according to Megawangi is an effort to educate children so they can make decisions wisely and practice them in everyday life, so they can make a positive contribution to its environment (Fathurrochman and Apriani 2017). In harmony with moral education is a conscious and unconscious effort undertaken by an educator to shape character. Strengthening character education in the present context is very relevant to overcoming the moral crisis that is happening in our country. Recognized or not recognized when there is a real and worrying crisis in society by involving our most valuable possessions, namely children,crime against friends, teen theft, cheating habits. Our youthful behavior is also colored by cheating, bullying habits at school, and brawl. The consequences are quite serious and can no longer be considered a simple matter because this action has led to criminal acts (Karolina 2018).

Based on the 2013 curriculum, that creates a quality and moral generation. Through the curriculum, students will be encouraged to become creative, productive, innovative and affective people through balanced competence between spiritual, knowledge, attitudes, and skills (Muchtar and Suryani 2019). The main values that must be achieved in learning in educational institutions include (1) Religion, (2) Honesty, (3) tolerance, (4)discipline, (5)hard work, (6) creative, (7) Independence, (8)democratic, (9) curiosity, (10)spirit of nationality, (11) Love the motherland, (12) appreciatin achievement, (13) friendly or communicative, (14) peace in love, (15) like to 
read, (16) Care for the environment, (17) social care, (18)responsibility(Muchtar and Suryani 2019). From these 18 aspects there are only 5 highest aspects which are implemented by English lecturers in the learning process.

The first highest aspect is the religious aspect. This percentage is $60.6 \%$. The

statements used are "assalamualaikum, bismillahirohmanirrohim and alhamdulill ahirrobbil alamin" in starting and ending learning. This proves that the lecturer has applied this aspect in the teaching and learning process. Lecturers always apply the pronunciation "assalamualaikum warrohmatullahi wabarokatu" in teaching English courses which then only starts with greetings "good morning, or good afternoon. Alhamdulillahirrobilalamin, this is in line with the theory put forward by CY Glock and R. Stark in his book, American Devotion: Religious Commitment Maturity. There are five dimensions in religiosity (Yanuarti 2018). Religious practice (Ritual Dimension) is the extent to which a person performs ritual obligations in his religion, such as pursuing prayer, fasting, almsgiving, etc. that is, seeing one's religion from carrying out ritual obligations in religion or harmony God, where that person is always obedient to the teachings of his religion (Swandar 2017).

The second highest aspect out of 18 aspects is the discipline aspect with a percentage of $48.8 \%$. The statement of these aspects is that the lecturer uses clothes according to the IAIN Curup code of ethics. This proves that the English teacher has applied clothes according to the IAIN Curup code of ethics. In line with disciplinary action that shows orderly and obedient behavior in various rules and regulations. Lickona explained that: the moral education approach to discipline uses discipline as a tool to teach the values of respect and responsibility. That is, learning the value of discipline using discipline as a tool to teach the values of respect and responsibility (Apriani, Wangid, and Yogyakarta 2015).

The third highest aspect is the Aspect Appreciating Achievement with a percentage of $47.2 \%$. The statement used is that the lecturer gives high motivation to students to continue learning. this is proof that lecturers of English study programs always provide motivation to learn for students to continue to improve their learning achievement, especially English is a subject related to learning a foreign language and to be able to communicate using English. In 
line with this, the Character of Appreciating Achievement is attitude, and actions that encourage it to produce something that is beneficial to society and recognize and appreciate the success of others. This is in line with the opinion of that intrinsic motivation to learn something can be improved by using interesting materials and ways such as the use of films, guest lecturers, demonstrations, and so on. The use of animated videos is expected to increase student motivation by presenting interesting audio and visual elements. (Dari and Fisika n.d.)

The fourth highest aspect, namely the democratic aspect. the percentage is $44.2 \%$. statement of this aspect namely lecturers are open in accepting student opinions. this is evidence that the lecturer has implemented the democratic aspect of the learning process by accepting students' opinions in the teaching and learning process. This is in line with the opinion of Septiliana year 2010 is the part of a person's personality that encourages to act in accordance with the values contained in democracy, namely tolerance, freedom of opinion, respect for differences of opinion, understanding diversity in society, open and communication, upholding values and Human dignity, self confidence, do not depend on others, respect each other, are able to restrain themselves, togetherness and balance (Fitriah, Muchyidin, and Sahrodi 2015).

The fifth highest aspect is the spirit of nationality aspect with a percentage of $43.3 \%$. statements in this aspect are the lecturers commemorate national (Indonesian Independence day, Heroes day, mother's day, etc) and Islamic day (Maulid of the Prophet Muhammad SAW, Halal bi halal, Islamic Miraj, Islamic new year, etc). This proves that the lecturer has implemented aspects of the spirit of nationality in teaching English. In line with in The character of the spirit of nationalism is a way of thinking, acting and having insight that places the interests of the nation and the State over the interests of themselves and their groups. The value of the spirit of nationalism is a way of thinking, acting and insight that places the interests of the nation and state above self and group interests. The value of patriotism is a way of thinking, acting and acting that shows loyalty, care and high respect for the language, physical environment, social, culture, economy and politics of the nation (Muchtar and Suryani 2019). 


\section{Conclusion}

From these explanations there are 18 aspects of Islamic character but in the results of the presentation it can be seen that the English tadris lecturers in the English study program at IAIN Curup only apply 5 aspects, namely religion, discipline, achievement awards, democracy, and the spirit of nationalism. while 13 other aspects, namely honesty, tolerance, hard work, creative, independence, curiosity, love the motherland, friendly or communicative, peace-loving, like to read, care about the environment, social care, responsibility, is still not implemented in the learning process. Which aspects should be important in the formation of character for students, but the lecturer can be categorized as not implementing it in the learning process. From the results of this study the values of Islamic character applied by the tadris language lecturers are still very few or even less than $50 \%$ of the 18 aspects according to the Ministry of Education and Culture. So, this proves that the English tadris lecturer is still lacking in applying his Islamic character. which should be implemented more by lecturers when teaching because remember they are lecturers within the scope of Islamic-based tertiary institutions. therefore, from this study English lecturers at IAIN Curup must be further improved in implementing Islamic character values in the teaching and learning process of English courses.

\section{References}

Adu, La. (2014). Pendidikan Karakter Dalam Perspektif Islam. Biology Science and Education 3(2), 68-78.

Ainissyifa, H. (2014). Pendidikan karakter dalam pendidikan islam. Pendidikan Universitas Garut 8(1), 1-26.

Amelia, Riza. (2012). Merancang Pembelajaran Bahasa Inggris Berbasis Pendekatan Islami. Jurnal Pemikiran Islam 37(1):8-15.

Apriani, A., Wangid, M. (2015). Pengaruh Ssp tematik-integratif terhadap karakter disiplin dan tanggung jawab siswa kelas lii Sd. Jurnal Prima Edukasi $3(1), 12-25$.

Apriani, E. (2017). Utilizing Preservice English Teachers Strategies and Classroom Management Junior High School in Rejang Lebong Regency. English Franca 1(02), 1-14.

Apriani, E., Fathurrochman, I., \& Harmi, H. (2018). The Role of Islam Rahmat Lil 'Alamin as the solution for exclusive Life in Indonesia. AJIS: Academic Journal of Islamic Studies . 3(2), 192. 
Arif, R.M. (2017). Implementasi pendidikan karakter dalam pembelajaran sains. STILISTIKA: Jurnal Bahasa, Sastra, Dan Pengajarannya 2(1), 83-96.

Aziz, A. (2015). Pendidik profesional yang berjiwa Islami. Studi Islam 10(1), 123.

Fathurrochman, et al. (2017). Pendidikan Karakter prespektif pendidikan Islam....." POTENSIA: Jurnal Kependidikan Islam 3(1),122-42.

Fitri, A. (2018). "Pendidikan Karakter Prespektif Al-Quran Hadits." Ta'lim: Jurnal Studi Pendidikan Islam 1 (2):258-87.

Fitriah, et al. (2015). Implementasi model pembelajaran matematika berintegrasi keislaman dalam meningkatkan karakter demokrasi siswa. Eduma : Mathematics Education Learning and Teaching 4(2).

Gusmuliana, P., \& Mardiana, F. (2016). The effect of using wordless picture books strategy on students' ability in writing narrative paragraph. ljielt 2(2), 171-84.

Diani, I., Yunita, W., \& Syafryadin, S. (2019). Interferensi Bahasa Indonesia terhadap Kemampuan Berbicara Bahasa Inggris Mahasiswa Universitas Bengkulu. In Seminar Nasional Pendidikan Bahasa dan Sastra. 1 (1), 164-173.

Karolina, A. (2018). Rekonstruksi pendidikan islam berbasis pembentukan karakter: dari konsep menuju internalisasi nilai-nilai Al-Quran. Jurnal Penelitian 11 (2), 237-66.

Muchtar, D., \& Suryani. A. (2019). Pendidikan karakter menurut Kemendikbud. Edumaspul: Jurnal Pendidikan 3(2), 50-57.

Omeri, N. (2005). Pentingnya pendidikan karakter dalam dunia pendidikan. Nopan Omeri 9(manager pendidikan), 464-68.

Wulan, R. (2016). The Implementation of the character appreciates the achievement of students in physics learning penerapan karakter menghargai prestasi siswa dalam.

Sabila, A. (2015). Karakter berbicara dosen pada mata kuliah sosiolinguistik. Jurnal Pesona. 1(2), 117-28.

Swandar, R.(2017). Implementasi pendidikan karakter religius Di SD Budi Mulia Dua Sedayu Bantul. Laporan Penelitian Yogyakarta: PGSD, Universitas PGRI Yogyakarta.

Syafryadin, W., \& DEC, A. Noermanzah.(2020). Maxim variation, conventional, and particularized implicature on students' Conversation. International Journal of Scientific and Technology Research, 9(2), 3271.

Syafryadin, S. (2020). Students' strategies in learning speaking: experience of two indonesian schools. Vision: Journal for Language and Foreign Language Learning, 9(1), 33-46.

Yanuarti, E. (2018). Pengaruh Sikap religiusitas terhadap perilaku hidup bersih dan sehat masyarakat Kabupaten Rejang Lebong.jurnal kaian keisalaman dan kemasyarakatan, P3M STAIN Curup. 3(1), 3.

Yuliyawati, S. N. (2010). Karakter dosen wanita dalam pembelajaran. The 4th International Conference on Teacher Education, 4(1), 101-111. 